
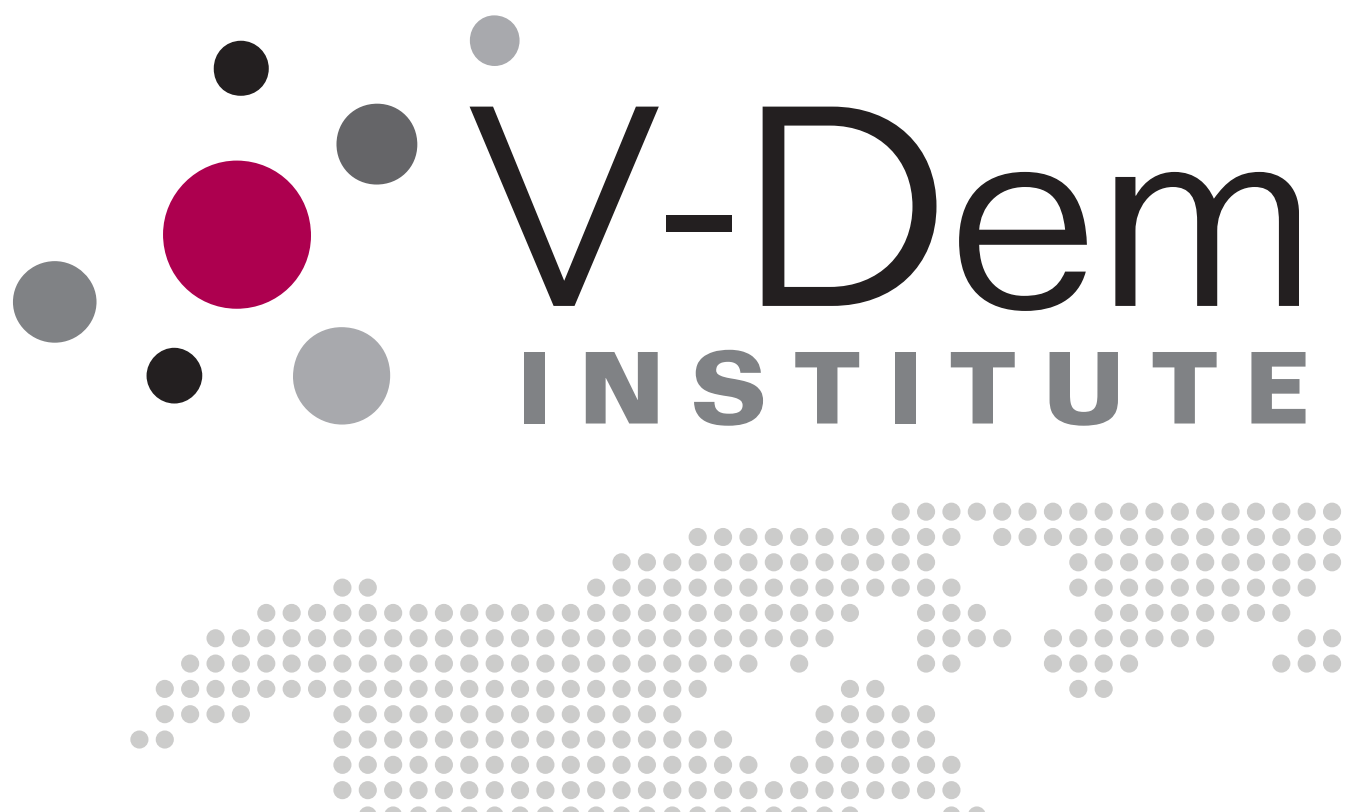

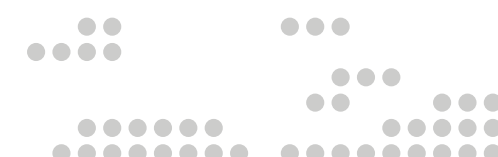

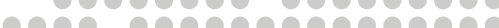
000000000000000000

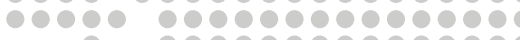
-

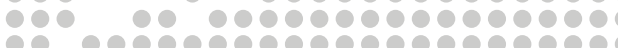

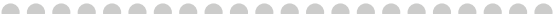

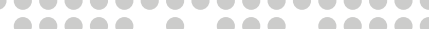

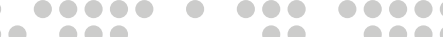

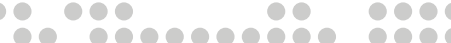

Measuring High Level Democratic Principles using the $V$-Dem Data

Michael Coppedge, Staffan I. Lindberg, Svend-Erik Skaaning and Jan Teorell 
Varieties of Democracy (V-Dem) is a new approach to the conceptualization and measurement of democracy. It is co-hosted by the University of Gothenburg and University of Notre Dame. With a V-Dem Institute at University of Gothenburg that comprises almost ten staff members, and a project team across the world with four Principal Investigators, fifteen Project Managers, 30+ Regional Managers, 170 Country Coordinators, Research Assistants, and 2,500 Country Experts, the V-Dem project is one of the largest-ever social science research-oriented data collection programs.

Please address comments and/or queries for information to:

V-Dem Institute

Department of Political Science

University of Gothenburg

Sprängkullsgatan 19, PO Box 711

SE 40530 Gothenburg

Sweden

E-mail: contact@v-dem.net

V-Dem Working Papers are available in electronic format at www.v-dem.net.

Copyright (C) 2015 by authors. All rights reserved. 


\title{
Measuring High Level Democratic Principles using the V-Dem Data*
}

\author{
Michael Coppedge \\ University of Notre Dame \\ Staffan Lindberg \\ University of Gothenburg \\ Svend-Erik Skaaning \\ Aarhus University \\ Jan Teorell \\ Lund University
}

\footnotetext{
* This research project was supported by Riksbankens Jubileumsfond, Grant M13-0559:1, PI: Staffan I. Lindberg, V-Dem Institute, University of Gothenburg, Sweden; by Swedish Research Council, PI: Staffan I. Lindberg, V-Dem Institute, University of Gothenburg, Sweden \& Jan Teorell, Department of Political Science, Lund University, Sweden; and by Knut \& Alice Wallenberg Foundation to Wallenberg Academy Fellow Staffan I. Lindberg, V-Dem Institute, University of Gothenburg, Sweden.
} 


\begin{abstract}
While the definition of extended conceptions of democracy has been widely discussed, the measurement of these constructs has not attracted similar attention. In this paper we present new measures of polyarchy, liberal democracy, deliberative democracy, egalitarian democracy, and participatory democracy that cover most polities in the period 1900 to 2013. These indices are based on data from a large number of indicators collected through the Varieties of Democracy (V-Dem) project. A discussion of the theoretical considerations and the concrete formula linked to our aggregation of indicators and components into high level measures is followed by an illustration of how these measures reflect variations in quality of democracy, given the respective ideals, in 2012. In the conclusion we urge scholars to make use of the rich dataset made available by V-Dem.
\end{abstract}




\section{Introduction}

It is a widespread assumption in democratic theory that democracy is more than free and fair elections. Theorists have suggested different models of democracy that seek to expand electoral definitions of democracy by emphasizing liberal constitutionalism, popular participation, socio-economic equality, or deliberation (Held 2006; Cunningham 2002; Coppedge et al. 2011). However, while the definition of extended conceptions of democracy has been discussed in a plethora of studies, the measurement of these constructs has not attracted similar attention. In fact, nearly all cross-national measures of democracy attempt to capture electoral or liberal definitions (Coppedge et al. 2011).

Partial exceptions do exist: The Discourse Quality Index is developed to reflect deliberative democracy (Steiner 2012), and the Participation Enhanced Polity Score is meant to capture participatory democracy (Moon et al. 2006). In addition, the democratic quality indices by Ringen (2007), Morlino (2011), Bühlmann et al. (2012), and the Bertelsmann Foundation (2014) go beyond electoral and liberal features and attempt also to measure egalitarian and/or participatory aspects of democracy. However, even though all of these attempts are praiseworthy, there is clearly room to improve the validity and reliability of measurement and to measure these diverse aspects of democracy in a more extensive set of countries and years.

Against this backdrop, we present new measures of polyarchy, liberal democracy, deliberative democracy, egalitarian democracy, and participatory democracy that cover most polities in the period 1900 to 2013 (Coppedge et al. 2015a; Lindberg et al. 2014). These indices are based on data from a large number of indicators collected through the Varieties of Democracy project (Coppedge et al. 2015b; see also www.V-Dem.net). In what follows we briefly describe the V-Dem dataset with a special emphasis on the indicators and components tapping into liberal, egalitarian, participatory, and deliberative aspects of political regimes. Thereafter, we discuss the theoretical considerations and the concrete formula linked to our aggregation of these aspects with polyarchy into high level measures of liberal democracy, egalitarian democracy, participatory democracy, and deliberative democracy. Finally, we illustrate how these measures reflect variations in quality of democracy, given the respective ideals, in 2012 . 


\section{The Varieties of Democracy (V-Dem) Dataset}

Three features in particular characterize the uniqueness of the V-Dem data. The first is radical disaggregation: The abstract theoretical principles of democracy are translated into more than 400 detailed questions with well-defined response categories or measurement scales.1 Second, the bulk of the data stems from almost 200 indicators collected from country experts, mostly academics from each country in question. The experts have been recruited based on their academic or other credentials as field experts in the area for which they code. (The questions are subdivided into 11 different areas of expertise, and most experts code only up to three areas.) Typically, a minimum of five independent experts respond to each question for each country and year going back to 1900 . Thus, more than 2,600 experts from countries over the entire globe have helped us gather the data. While we select experts carefully, they clearly exhibit varying levels of reliability and bias. In addition, some periods are naturally more unknown than others, varying both across country-years and different sets of indicators. Therefore - and this is the third unique feature of V-Dem - we use Bayesian ordinal item response theory (IRT) modeling techniques to estimate latent country coding unit characteristics from our collection of expert ratings (see Pemstein et al. 2015). At present (i.e., April 2015), we have completed data collection for 173 countries or semi-sovereign territories.

In this article we focus on the measurement of five key principles or traditions that offer distinctive approaches to defining democracy—electoral, liberal, participatory, deliberative, and egalitarian. There is a thin and a thick version for each of these principles. The thin version, which we refer to as its "component," includes only the most distinctive attributes of that principle, minimizing its overlap with the other principles. Thus, we refer to a "liberal component," a "deliberative component," and so on, which are designed to be conceptually distinct even though they may be empirically correlated.

- The electoral component of democracy embodies the core value of making rulers responsive to citizens through competition for the approval of a broad electorate during periodic elections. In the V-Dem conceptual scheme, the electoral component is fundamental; without it, we cannot call a regime "democratic" in any sense. At the same time, we recognize that holding elections alone is insufficient, and also that countries can have "democratic qualities" without being electoral democracies.

\footnotetext{
${ }^{1}$ A listing of all of the components, subcomponents, and indicators included in each of the democracy indices is available in the online appendix to this article. For details on all the over 400 indicators supplied by V-Dem, see the V-Dem Codebook v4 available at https://v-dem.net.
} 
- The liberal component of democracy embodies the intrinsic value of protecting individual and minority rights against a potential "tyranny of the majority." This is achieved through constitutionally protected civil liberties, strong rule of law, and effective checks and balances that limit the use of executive power.

- The participatory component embodies the values of direct rule and active participation by citizens in all political processes; it emphasizes non-electoral forms of political participation such as through civil society organizations and mechanisms of direct democracy.

- The deliberative component enshrines the core value that political decisions in pursuit of the public good should be informed by respectful and reasonable dialogue at all levels rather than by emotional appeals, solidary attachments, parochial interests, or coercion.

- The egalitarian component holds that material and immaterial inequalities inhibit the actual exercise of formal rights and liberties; hence a more equal distribution of resources, education, and health across various groups should enhance political equality.

\section{Aggregating Components into High Level Indices}

We also recognize the need for "full" democracy indices that reflect the varying schools of thought. The first step is to focus on electoral democracy. We have opted to capture Dahl's (1998) concept of polyarchy, which identifies the following political institutions as constitutive of modern representative democracy: 1) elected officials, 2) free, fair, and frequent elections, 3) freedom of expression, 4) alternative sources of information, 5) associational autonomy, and 6) inclusive citizenship. The V-Dem Electoral Democracy index measures these features using the elected executive index (v2x_accex, based on 12 indicators), the clean elections index (v2xel_frefair, based on 8 indicators), the freedom of expression index (v2x_freexp_thick, based on 9 indicators, including 3 for alternative sources of information), the freedom of association index (v2x_frassoc_thick, based on 6 indicators), and the suffrage indicator (v2x_suffr); all range from 0 to 1 . To construct the Electoral Democracy index we have used this aggregation formula: 
Electoral Democracy (polyarchy) $=$

$.1 *$ elected executive $+.1 *$ clean elections $+.1 *$ freedom of expression $+.1 *$ freedom of association $+.1^{*}$ suffrage $+.5^{*}$ elected executive $*$ clean elections $*$ freedom of expression $*$ freedom of association * suffrage.

In our view this aggregation rule reflects how the different parts are related to - and contribute to - the overarching concept. On the one hand, the five-way interaction between the different attributes, which receives half of the weight, causes a high score on one indicator to be dragged down by a low score on another. The logic is that to some extent the contribution of one attribute depends on the presence of the other. If, say, oppositional candidates are not allowed to run for election, or the elections are fraudulent, it does not matter much for the level of electoral democracy that all adults have voting rights. On the other hand, we think that it should matter something rather than nothing, which is the reason for giving some weight to the individual features. As a consequence, our formula is situated half way between a straight average and strict multiplication. It is thus a compromise between the two best known aggregation formulas in the literature, both allowing some "compensation" in one sub-component for lack of polyarchy in the others, but also punishing countries not strong in one sub-component.

We then construct the "thick" versions of each of the alternative principles of democracy. They all include one overlapping element - namely, electoral democracy, as we believe that no regime should be called a "democracy" of any type unless it builds on this foundation. In order to create measures that reflect the varying definitions of democracy, we thus need to combine the scores for our Electoral Democracy (polyarchy) Index with the scores for the components measuring deliberation, equality, participation, and liberal constitutionalism, respectively. This is not an easy task. Imagine two components, $\mathrm{P}=$ Polyarchy and $\mathrm{HPC}=$ High Principle Component (liberal, egalitarian, participatory, or deliberative), 2 that we want to aggregate into a more general highlevel index, called an HLI (Deliberative Democracy Index, Egalitarian Democracy Index, and so on). For convenience, both P and HPC are scaled to a continuous 0-1 interval. Based on extensive deliberations among the authors and other members of the V-Dem research group, we have tentatively arrived at the following aggregation formula:

$$
\mathrm{HLI}=.25 * \mathrm{P}^{1.6}+.25 * \mathrm{HPC}+.5 * \mathrm{P}^{1.6 *} \mathrm{HPC}
$$

\footnotetext{
2 The HPCs are indices based on the aggregation of a large number of indicators (liberal=23, egalitarian=8, participatory $=21$, deliberative $=5$ ).
} 
Without going into detail, the underlying rationale for this formula, which we apply to all four HLIs, is the following. A "classical" definition, based on necessary and sufficient conditions, would put all the emphasis on the combination of Polyarchy and HPC, that is, the interaction term. According to this view, Deliberative Democracy, for example, requires deliberation and Polyarchy. However, we also see some legitimacy in "family resemblance" definitions, which allow for the HLI to be satisfied by Polyarchy or deliberation, corresponding to substitutability between the additive terms in the equation. In essence, by including both the additive and interaction terms and weighting them according to the number of components they reflect, we give equal weight to the classical and family resemblance definitions: half the weight to the additive terms and half to the multiplicative interaction.

Second, the more the country approximates Polyarchy, the more the combined HLI score for a country should reflect the unique component. This perspective is an incremental version of theoretical arguments presented in the literature saying that polyarchy or electoral democracy conditions should be satisfied before the other democracy component contribute much to the high level index values. At the same time, it reflects the view in the literature that when a certain level of polyarchy is reached, what matters in terms of, say, participatory democracy is how much of the participatory property of democracy the country has. This argument also resembles a widespread perspective in the quality of democracy literature emphasizing that the fulfillment of some baseline democracy criteria are needed before it makes sense to assess the quality of democracy. (For an overview, see Munck 2015.) The question then becomes at what rate this influence should increase. We arrived at the power parameter of 1.6 by defining an anchor point: When a country is a pure hybrid regime, i.e., the polyarchy score is .5 (in practice, this is largely the breaking point where countries would be considered electoral democracies in a minimal sense), and HPC is at its maximum (=1), the high level index score should be set at .5.3

Collectively, these thick versions of the five concepts are what we refer to as "varieties of democracy." We argue that, taken together, these offer a fairly comprehensive accounting of the concept of democracy.

\footnotetext{
3 Define the power parameter as $p$. Setting Polyarchy=.5, HPC=1, and HLI=.5, and solving for $\mathrm{HLI}=.25 *$ Polyarchy $^{\wedge} p+.25 * \mathrm{HPC}+.5 *$ Polyarchy^ $\mathrm{p}^{*} \mathrm{HPC}, p=\log ($ base 0.5$)$ of $.25 / .75 \approx 1.6$.
} 


\section{Descriptive Patterns}

Figures 1-4 are three-dimensional scatter plots showing the relationships between each HLI, the Electoral Democracy Index ("Polyarchy"), and the corresponding High Principle Component in 2012. Selected well-known countries in all ranges of values are labeled. Each graph is rotated differently to enhance the visibility of the spikes for the selected countries. Although countries that are conventionally considered democratic, such as Britain, France, Switzerland, and the United States are found near the top of each figure and highly undemocratic countries such as Saudi Arabia, North Korea, and Eritrea are found near the bottom, there are differences. First, countries are more dispersed on the egalitarian component than on the other components. This makes it possible for Cuba to get a very high score on the egalitarian component but a low score on electoral democracy, and therefore a rather low score on egalitarian democracy. In the high corner of the same figure, the United Kingdom, France, and Switzerland score higher than the United States on egalitarian democracy, while the United States is near the top on liberal and deliberative democracy. Switzerland and Uruguay have the highest scores on participatory democracy due to their generous provisions for direct democracy mechanisms. On the deliberative democracy plot, China has an electoral democracy score close to those of North Korea and Turkmenistan, but its deliberative democracy score is noticeably higher because North Korea and Turkmenistan had far more autocratic leaders in 2012. Many other comparisons could be made, but these help establish the validity of these indices. 
Figure 1. The relationships between Egalitarian Democracy Index, the Electoral Democracy Index ("Polyarchy"), and Egalitarian Component in 2012.

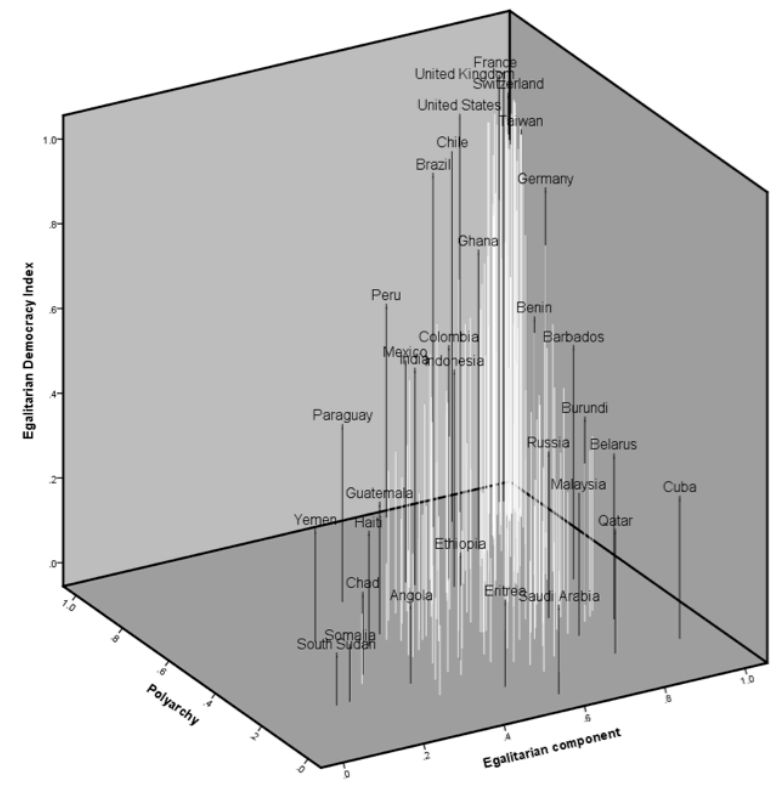

Figure 3. The relationships between Liberal Democracy Index, the Electoral Democracy Index ("Polyarchy"), and Liberal Component in 2012.

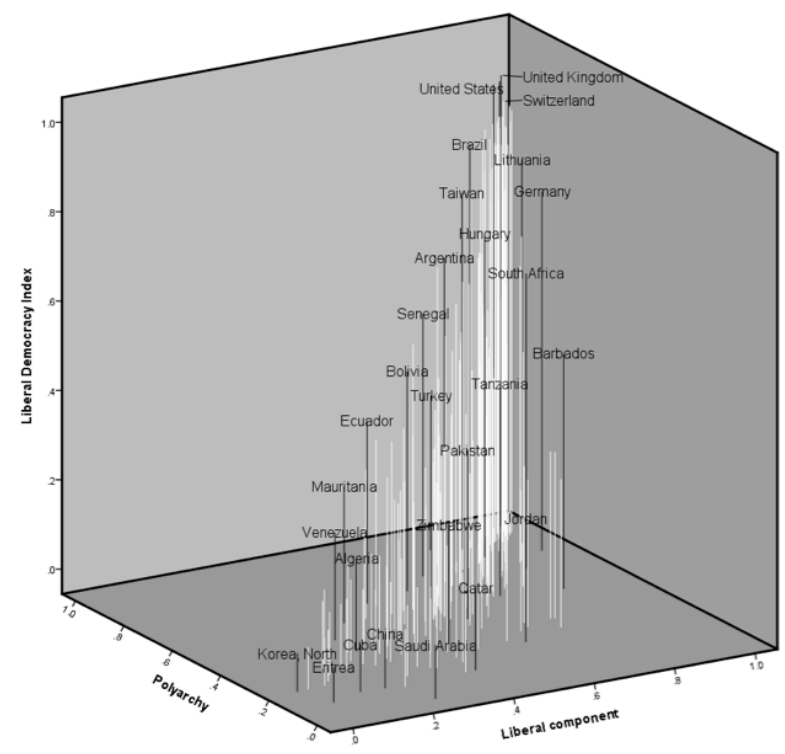

Figure 2. The relationships between Deliberative Democracy Index, the Electoral Democracy Index ("Polyarchy"), and Deliberative Component in 2012.

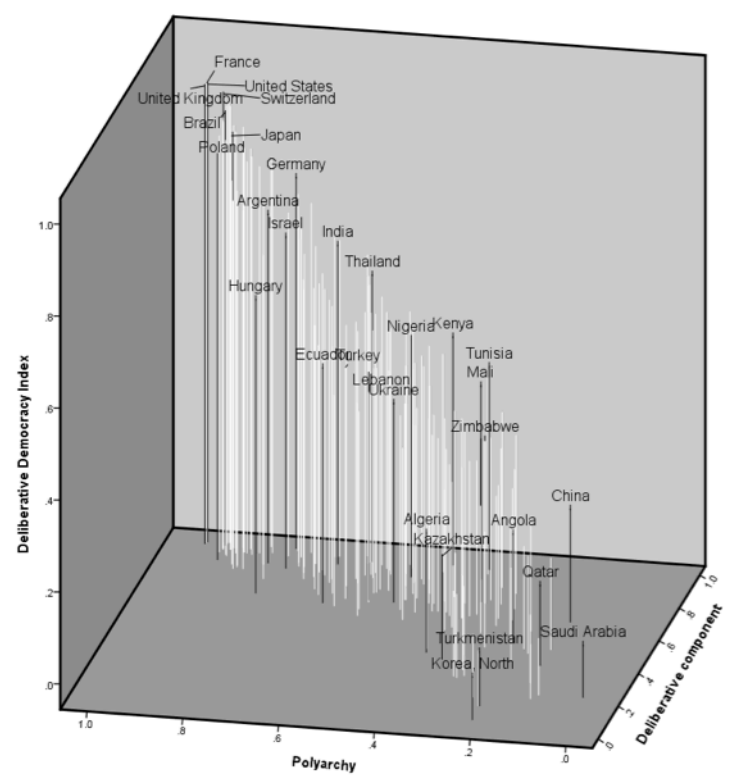

Figure 4. The relationships between Participatory Democracy Index, the Electoral Democracy Index ("Polyarchy"), and Participatory Component in 2012.

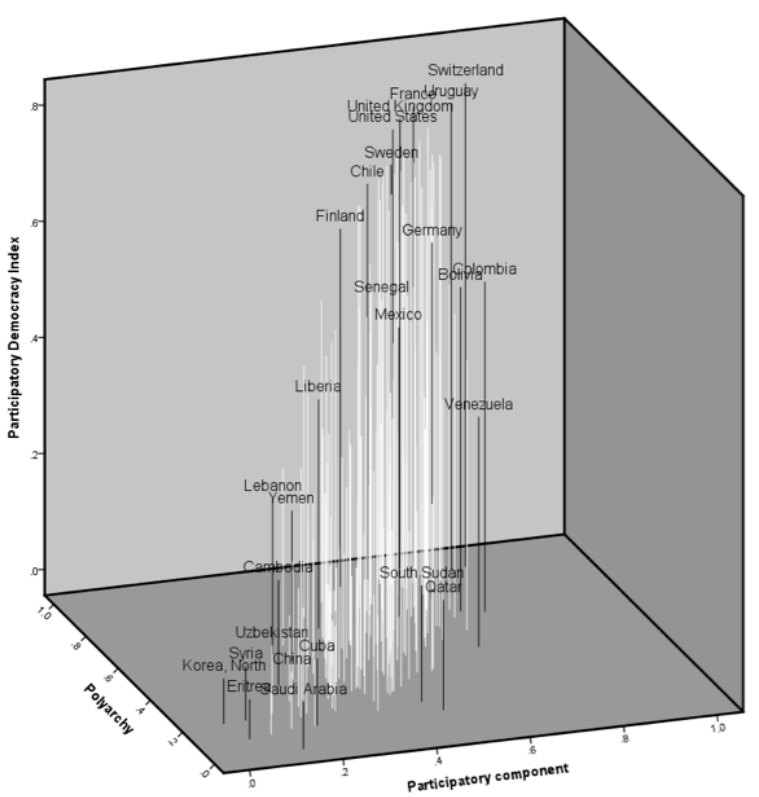




\section{Conclusion}

Over the recent decades we have witnessed an increased interest from academics, NGOs, and politician in the measurement of conceptions of democracy that go beyond electoral aspects. However, country-specific assessments have hardly been followed by the development of large cross-national datasets aimed at capturing these non-electoral aspects. In this short paper, we have demonstrated that the V-Dem dataset provides a large number of relevant indicators, covering most polities of the world from 1900 and onwards. Furthermore, we have presented our aggregation scheme, and we have shown the resulting scores can be used to capture similarities and differences in democratic quality across space and time, as measured by the different high level indices for liberal democracy, deliberative democracy, egalitarian democracy, and participatory democracy, respectively.

These graphs revealed interesting patterns. Nonetheless, for many purposes, we recommend scholars and practitioners alike to make use of the more nuanced disaggregated data made available by V-Dem. Nuances get lost when many indicators are combined into subcomponents, components, and high level indices. Moreover, many aggregation rules are possible; we do not claim that the ones presented here are the best for every application, although in our experience most aggregation rules yield high correlated scores with these data. We are ready to enter open-minded discussions about these issues. Most importantly, the raw data on indicators and the indices, along with $95 \%$ confidence bounds, will be available by December 31, 2015 for everyone to use as they see fit. 


\section{References}

Bertelsmann Foundation (2014). Transformation Index BTI 2014. Gütersloh: Verlag Bertelssmann Stiftung.

Bühlmann, Marc; Wolfgang Merkel; Lisa Müller \& Bernhard Wessels (2012). “The Democracy Barometer: A New Instrument to Measure the Quality of Democracy and its Potential for Comparative Research.” European Political Science 11(4): 519-536.

Coppedge; Michael and John Gerring with David Altman, Michael Bernhard, Steven Fish, Allen Hicken, Matthew Kroenig, Staffan I. Lindberg, Kelly McMann, Pamela Paxton, Holly A. Semetko, Svend-Erik Skaaning; Jeffrey Staton \& Jan Teorell (2011). "Defining and Measuring Democracy: A New Approach.” Perspectives on Politics 9(2): 247-267.

Coppedge, Michael, John Gerring, Staffan I. Lindberg, Jan Teorell, David Altman, Michael Bernhard, M. Steven Fish, Adam Glynn, Allen Hicken, Carl Henrik Knutsen, Kelly McMann, Daniel Pemstein, Megan Reif, Svend-Erik Skaaning, Jeffrey Staton, Eitan Tzelgov, Yi-ting Wang, and Brigitte Zimmerman. 2015a. Varieties of Democracy: Methodology 44. Varieties of Democracy (V-Dem) Project.

Coppedge, Michael, John Gerring, Staffan I. Lindberg, Jan Teorell, David Altman, Michael Bernhard, M. Steven Fish, Adam Glynn, Allen Hicken, Carl Henrik Knutsen, Kelly McMann, Daniel Pemstein, Megan Reif, Svend-Erik Skaaning, Jeffrey Staton, Eitan Tzelgov, and Yi-ting Wang. 2015b. Varieties of Democracy: Codebook v4. Varieties of Democracy (V-Dem) Project.

Cunningham, Frank (2002). Theories of Democracy: A Critical Introduction. London: Routledge.

Dahl, Robert (1998). On Democracy. New Haven: Yale University Press.

Held, David (2006). Models of Democracy. Cambridge: Polity.

Lindberg, Staffan I., Michael Coppedge, John Gerring, and Jan Teorell. 2014. “A New Approach to Measuring Democracy". Journal of Democracy 25(3): 159-169.

Moon, Bruce E.; Jennifer H. Birdsall; Sylvia Ciesluk; Lauren M. Garlett; Joshua J. Hermias; Elizabeth Mendenhall; Patrick D. Schmid \& Wai Hong Wong (2006). "Voting Counts: Participation in the Measurement of Democracy." Studies in Comparative International Development 41(2): 3-32.

Morlino, Leonardo (2011). Changes for Democracy. Actors, Structures, Processes. Oxford: Oxford University Press.

Munck, Gerardo (2015). "What is democracy? A Reconceptualization of the Quality of Democracy." Democratization. 
Ringen, Stein (2007). What Democracy Is For: On Freedom and Moral Government. Princeton: Princeton University Press.

Steiner, Jürg (2012). The Foundations of Deliberative Democracy: Empirical Research and Normative Implications. Cambridge: Cambridge University Press. 


\section{Appendix 1: List of all of the components and subcomponents included in each index}

Index/Indicator Name Components, subcomponents, indicators, and aggregation rules

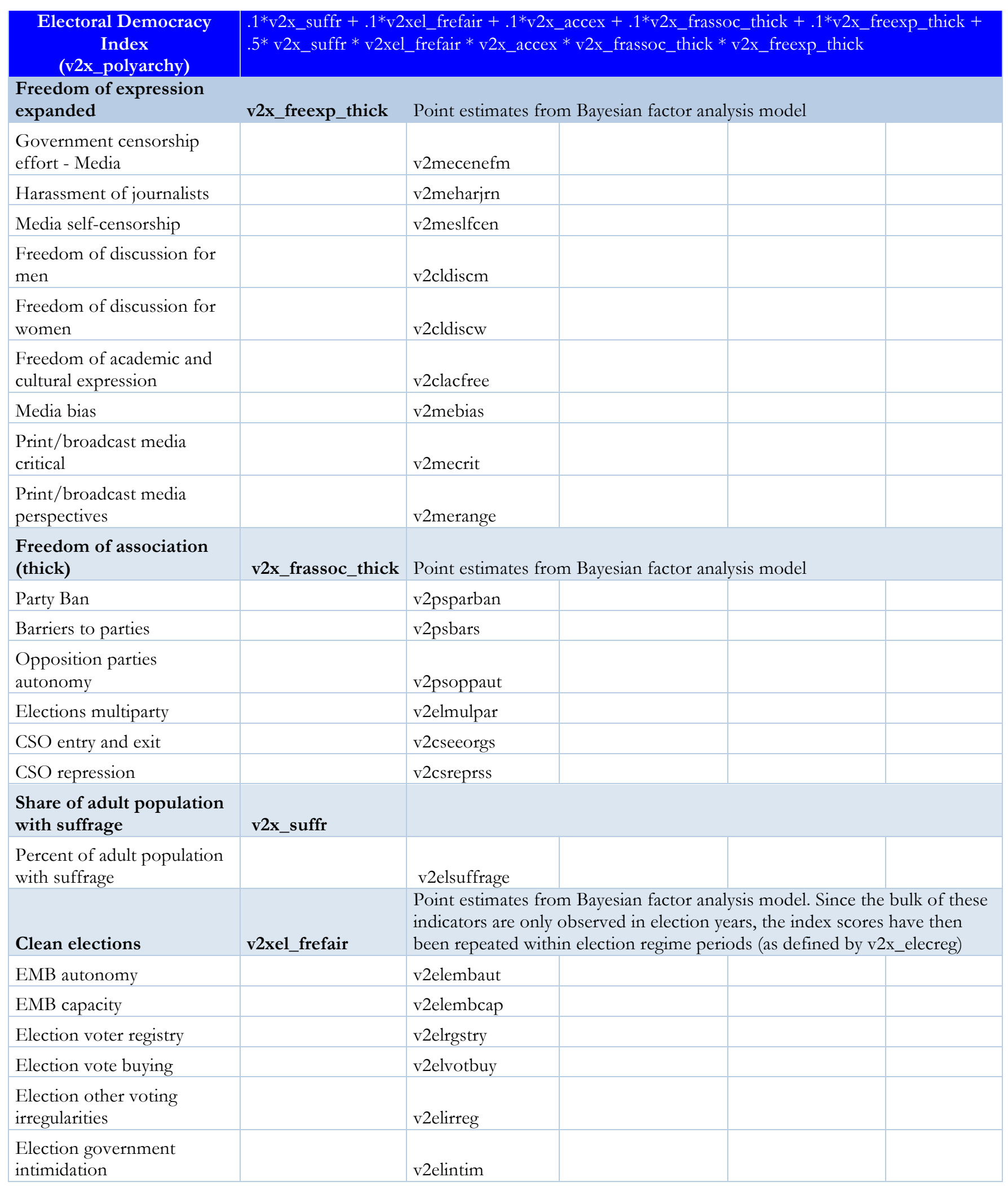


Election other electoral violence

Election free and fair

Elected executive (de jure)

Lower chamber elected

Upper chamber elected

Legislature dominant

chamber

HOS selection by legislature

in practice

HOS appointment in

practice

HOG selection by

legislature in practice

HOG appointment in

practice

HOS appoints cabinet in

practice

HOG appoints cabinet in

practice

HOS dismisses ministers in practice

HOG dismisses ministers in practice

v2exdfdshg

HOS appoints cabinet in

practice

v2elpeace

\section{v2elfrfair} hosw. v2lgello

v2lgelecup

v2exaphos

v2expathhs

v2exaphogp

v2expathhg

v2exdfcbhs

v2exdjcbhg

v2exdfcbhs
Six different chains of appointment/selection are taken into account. First, whether the head of state is directly elected $(a=1)$ or not $(a=0)$. Second, the extent to which the legislature is popularly elected (b), measured as the proportion of legislators elected (if legislature is unicameral), or the weighted average of the proportion elected for each house, with the weight defined by which house is dominant (if legislature is bicameral). Third, whether the head of state is appointed by the legislature, or the approval of the legislature is necessary for the appointment of the head of state $(\mathrm{c} 1=1$, otherwise 0$)$. Fourth, whether the head of government is appointed by the legislature, or the approval of the legislature is necessary for the appointment of the head of government ( $c 2=1$, otherwise 0$)$. Fifth, whether the head of government is appointed by the head of state $(d=1)$ or not $(d=0)$. Sixth, whether the head of government is directly elected $(\mathrm{e}=1)$ or not $(\mathrm{e}=0)$. Define hosw as the weight for the head of state. If the head of state is also head of government (v2exhoshog==1), hosw=1. If the head of state has more power than the head of government over the appointment and dismissal of cabinet ministers, then hosw $=1$; if the reverse is true, hosw $=0$. If they share equal power, hosw $=.5$. Define the weight for the head of government as hogw $=1$ -

hosw*[max $(\mathrm{a} 1, \mathrm{~b} * \mathrm{c} 1)]+\operatorname{hogw} *[\max (\mathrm{a} 1 * \mathrm{~d}, \mathrm{~b} * \mathrm{c} 1 * \mathrm{~d}, \mathrm{a} 2, \mathrm{~b} * \mathrm{c} 2)]$

v2lgdomchm

v2exdfdmhs

Liberal Democracy Index

(v2x_libdem) $.25^{*} \mathrm{v} 2 \mathrm{x} \_$polyarchy^ $1.6+.25^{*} \mathrm{v} 2 \mathrm{x} \_$liberal $+.5^{*} \mathrm{v} 2 \mathrm{x} \_$polyarchy ${ }^{\wedge} 1.6^{*} \mathrm{v} 2 \mathrm{x} \_$liberal

Electoral Democracy

Index

v2x_polyarchy 


\begin{tabular}{|c|c|c|c|}
\hline $\begin{array}{l}\text { Rigorous and impartial } \\
\text { public administration }\end{array}$ & & v2clrspct & \\
\hline $\begin{array}{l}\text { Transparent laws with } \\
\text { predictable enforcement }\end{array}$ & & v2cltrnslw & \\
\hline Access to justice for men & & v2clacjstm & \\
\hline Access to justice for women & & v2clacjstw & \\
\hline Property rights for men & & v2clprptym & \\
\hline Property rights for women & & v2clprptyw & \\
\hline Freedom from torture & & v2cltort & \\
\hline $\begin{array}{l}\text { Freedom from political } \\
\text { killings }\end{array}$ & & v2clkill & \\
\hline $\begin{array}{l}\text { Freedom from forced labor } \\
\text { for men }\end{array}$ & & v2clslavem & \\
\hline $\begin{array}{l}\text { Freedom from forced labor } \\
\text { for women }\end{array}$ & & v2clslavef & \\
\hline Freedom of religion & & v2clrelig & \\
\hline $\begin{array}{l}\text { Freedom of foreign } \\
\text { movement }\end{array}$ & & v2clfmove & \\
\hline $\begin{array}{l}\text { Freedom of domestic } \\
\text { movement for men }\end{array}$ & & v2cldmovem & \\
\hline $\begin{array}{l}\text { Freedom of domestic } \\
\text { movement for women }\end{array}$ & & v2cldmovew & \\
\hline $\begin{array}{l}\text { Judicial constraints on the } \\
\text { executive }\end{array}$ & $v 2 x_{-}$jucon & Point estimates from & Bayesian factor analysis model \\
\hline $\begin{array}{l}\text { Executive respects } \\
\text { constitution }\end{array}$ & & v2exrescon & \\
\hline Compliance with judiciary & & v2jucomp & \\
\hline Compliance with high court & & v2juhccomp & \\
\hline High court independence & & v2juhcind & \\
\hline Lowercourtindependence & & v2juncind & \\
\hline $\begin{array}{l}\text { Legislative constraints on } \\
\text { the executive }\end{array}$ & v2xlg_legcon & Point estimates from & Bayesian factor analysis model \\
\hline $\begin{array}{l}\text { Legislature questions } \\
\text { officials in practice }\end{array}$ & & v2lgqstexp & \\
\hline Executive oversight & & v2lgotovst & \\
\hline $\begin{array}{l}\text { Legislature investigates in } \\
\text { practice }\end{array}$ & & v2lginvstp & \\
\hline $\begin{array}{l}\text { Legislature opposition } \\
\text { parties }\end{array}$ & & v2lgoppart & \\
\hline
\end{tabular}

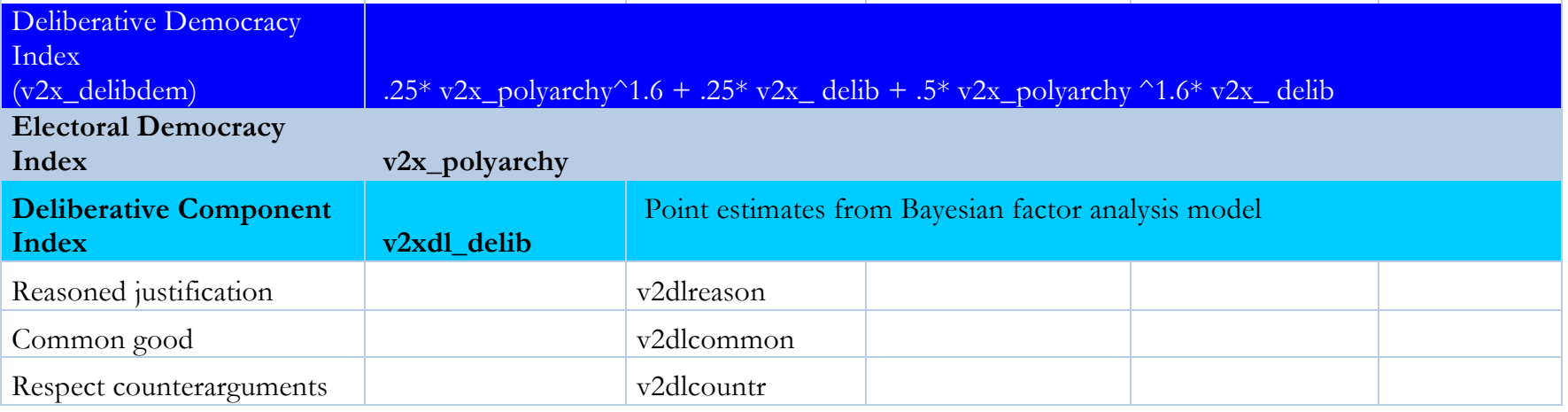


Range of consultation

Engaged society v2dlconslt

v2dlengage

\section{Egalitarian democracy Index}

Electoral Democracy

Index v2x_polyarchy

Egalitarian Component Index v2x_egal

Point estimates from Bayesian factor analysis model

Power distributed by socioeconomic position

Power distributed by social group

Social group equality in respect for civil liberties

Educational equality

Health equality

Power distributed by gender

Encompassing-ness

Means-tested vs.

universalistic

v2pepwrses
v2pepwrsoc
v2clsocgrp
v2peedueq
v2pehealth
v2pepwrgen
v2dlencmps
v2dlunivl

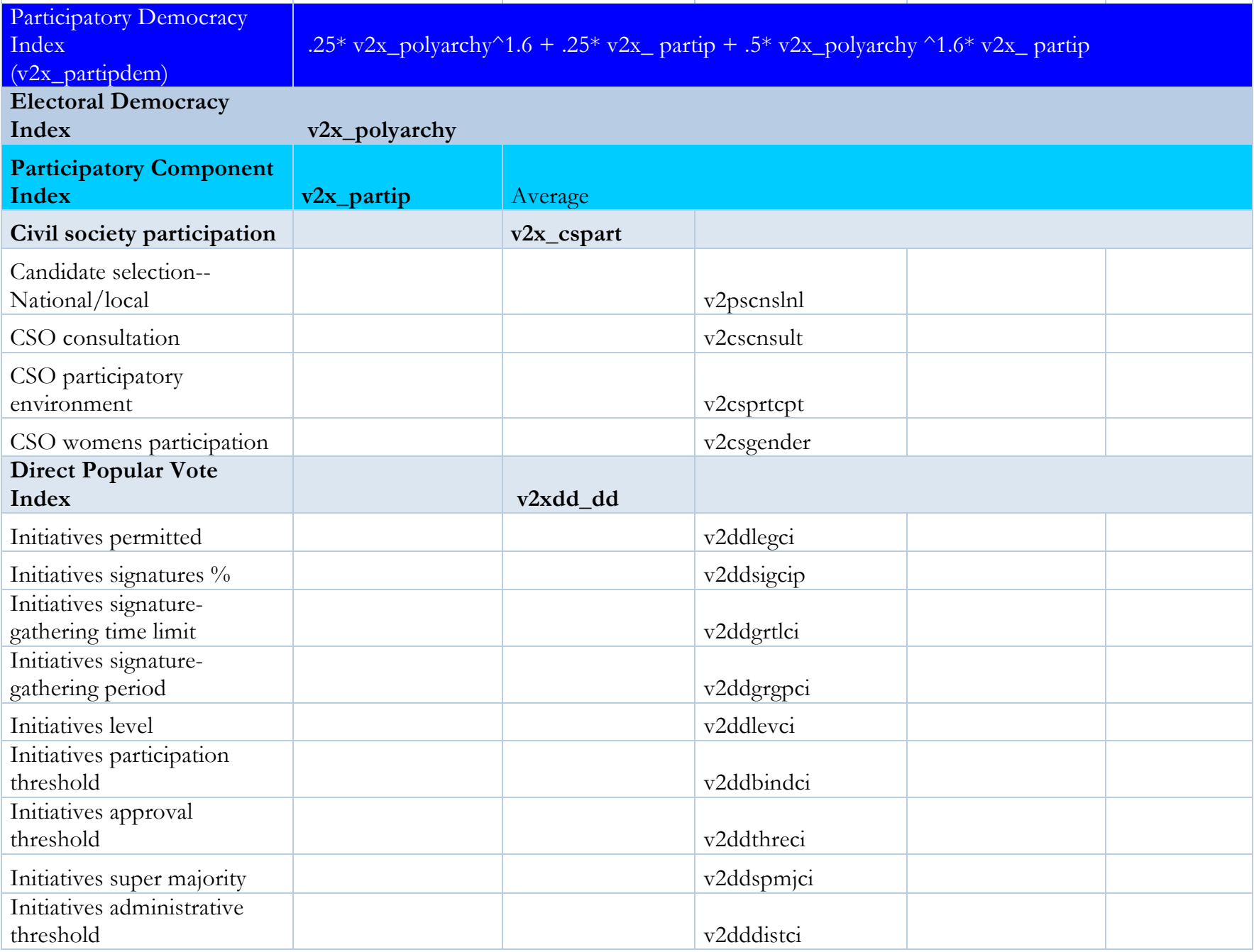


Initiatives permitted

Occurrence of citizen-

initiative this year

\section{Local Government}

Local government elected

Local offices relative power

Local government exists

Regional Government

Regional government

elected

Regional offices relative

power

Regional government exists v2ddlegci

v2ddciniyr

First, local government elected (v2ellocelc) is recoded so that $0=$ none elected, $1=$ only executive elected, $2=$ only assembly elected or both assembly and executive elected. This new construct is then scaled to vary from $0-1$ and multiplied by local offices relative power (v2ellocpwr) scaled to vary from $0-1$.

v2ellocelc

v2ellocpwr

v2ellocgov

First, regional government elected (v2elsrgel) is recoded so that $0=$ none elected, $1=$ only executive elected, $2=$ only assembly elected or both assembly and executive elected. This new construct is then scaled to vary from $0-1$ and multiplied by regional offices relative power (v2elrgpwr) scaled to vary from 0-1.

v2xel_regelec

v2elrgpwr

v2elreggov 